\title{
BIBECHANA
}

ISSN 2091-0762 (Print), 2382-5340 (Online)

Journal homepage: http://nepjol.info/index.php/BIBECHANA

Publisher: Department of Physics, Mahendra Morang A.M. Campus, TU, Biratnagar, Nepal

\section{Surface air temperature trends in Kathmandu Valley for 2011-2017}

\author{
A. Thapa ${ }^{1}$, A. Silwal ${ }^{1}$, P. Sharma ${ }^{1}$, S. P. Gautam ${ }^{2}$, C. K. Nepal ${ }^{1}$, S. Bhattarai ${ }^{1}$, D. Timsina ${ }^{1}$ \\ ${ }^{1}$ Patan Multiple Campus, Tribhuvan University, Lalitpur, Nepal \\ ${ }^{2}$ Central Department of Physics, Tribhuvan University, Kirtipur, Nepal \\ Email: ashoksilwal0@gmail.com
}

Article Information:

Received: June 17, 2020

Accepted: May 7, 2021

Keywords:

Air temperature

Kathmandu

DHM

Climate change

Precipitation

Rainfall

\begin{abstract}
In this study, we reviewed the maximum and minimum temperature trends of the Kathmandu valley over the period of 2011-2017. In addition, the average monthly temperature trends were studied annually for the same period, with the data made available from the Department of Hydrology and Meteorology (DHM) of Nepal. The annual temperature trended in the same direction, with winter temperatures being lower and summer temperatures being higher. The annual average minimum and maximum air temperature trends were found to be slightly rising at $0.097^{\circ} \mathrm{C} /$ year and $0.04^{\circ} \mathrm{C} /$ year, respectively. The mean air temperature in Kathmandu valley is increasing at a rate of 0.06 degrees Celsius per year, with 2016 being the warmest year and 2012 being the least warm, with annual mean temperatures of $19.82^{\circ} \mathrm{C}$ and $19.32^{\circ} \mathrm{C}$, respectively. The temperature difference is much smaller in the summer (less than $\sim 12^{\circ} \mathrm{C}$ ) than in the winter.
\end{abstract}

DOI: https://doi.org/10.3126/bibechana.v18i2.29495

This work is licensed under the Creative Commons CC BY-NC License. https://creativecommons.org/licenses/by-nc/4.0/

\section{Introduction}

Climate is a statistical description of surface variables like temperature, humidity, wind, atmospheric pressure over a long period of time [1]. Climate change is generally described as a statistically detectable change in climate that lasts for a long time, typically decades or longer [1]. The Earth's climate is primarily influenced by latitude, altitude, the tilt of the Earth's axis, temperature differences between land and sea, and topography [1]. Several lines of scientific evidence indicate that the Earth's atmosphere has changed over time, implying that the planet is warming [2]. Natural variability, on the other hand, cannot account for the recent observed warming. Over the last 200 years, the atmosphere has changed dramatically, and the explanation for this is the industrial revolution, which has resulted in a gradual rise in $\mathrm{CO}_{2}$ and other greenhouse gases due to the burning of fossil fuels. This fact is best supported by the Intergovernmental Panel on Climate Change (IPCC) report of 2014, where it is mentioned that more than $95 \%$ of the scientists were certain that we 
humans are primarily responsible for the climate change, mainly increasing concentrations of greenhouse gases such as carbon dioxide $\left(\mathrm{CO}_{2}\right)$ [2] . According to The Royal Society and the US National Academy of Sciences, the earth's global average temperature has risen by about $0.8^{\circ} \mathrm{C}$ since 1900 [3], which thus motivates us to look for the air temperature trend in these recent years since that rate of increase in temperature has not been evidenced before that in the earth's history. This transition is challenging for both the developing and developed worlds. Because of urbanization, there is less greenery and more impervious surfaces, resulting in changes in land cover, land use, and land surface characteristics, which modify the local climate, moisture exchange, and ecosystem services, favoring heat-trapping and storage $[4,5]$. Changes in land use and land cover affect air temperature by affecting the sensible and latent heat partitioning of usable resources $[6,7]$.

Understanding the climate change caused by different factors requires a thorough examination of historical climate changes. Air temperature is thought to be a significant predictor of climate among these variables. The broad knowledge and information gathered over a long period of time from continuous research and forecasts of climatic phenomena have guided us in understanding current weather conditions and predicting future fluctuations $[4,6]$. As a result, climatic change has a major impact on people's lives and the environment [8]. Local weather conditions, on the other hand are the most readily accessible data source since they can be aggregated over time to detect potential climate changes at the local scale [9]. Research on local climate knowledge has allowed people to detect and respond to the fluctuations in the climate [10]. The air temperature influences nearly every other weather parameter, including dew point temperature, precipitation, humidity, clouds, and air pressure, and is, therefore, a commonly measured variable that directly impacts $n$ weather change [11].

Nepal is located between the latitudes of $26^{\circ} 22^{\prime}$ and $30^{\circ} 27^{\prime} \mathrm{N}$, and the longitudes of $80^{\circ} 04^{\prime}$ and $88^{\circ} 12^{\prime} \mathrm{E}$.
The nation is 885 kilometers long from east to west, with a north-south distance ranging from 130 to 260 kilometers. From the southern plain (Terai) to Mount Everest in the northeast, the altitudinal variation varies between 60 and 8848 meters above mean sea level [12]. Altitude, prevailing winds, topography, and seasonal atmospheric circulations are all factors that influence Nepal's climate [13]. The present work aims to extend the analysis of Kathmandu, Nepal's monthly average air temperature from 2011 to 2017. This research will provide crucial information on the climatic variations in Nepal over the last seven years. We conclude that the findings of this study will serve as a baseline for predicting long-term climate trends by analyzing data at the local scale.

As shown by the recurring scientific and political discourse on these issues, scientists from all over the world show a high degree of uncertainty when analyzing and cross-referencing past and future records associated with climate change. This emphasizes the importance of accurate data, accurate research, and better science in order to improve our understanding of climate change based on local scale parameters [14]. Climate change analysis and forecasts in Nepal are still based on a literature review and some scattered data. There is still no strategy in place to collect long-term, highquality data that can be used to make accurate analyses and forecasts. A lot of research has been done in Nepal over the last few years as well. Shrestha et al. (1999) [15] studied the temperature trends of Nepal for the 18 years period (1977-1994) and found that the annual maximum temperature was increasing at the rate of $0.06^{\circ} \mathrm{C} /$ year. They further added that a significant increase in warming trends in the higher altitude regions of the Middle Mountain and the high Himalaya than in the Terai and Siwalik regions was observed [15]. Later on, in 2008 You et al. [16] investigated changes of eastern and central Tibetan plateau for the period of 19612005 and found that both minimum and maximum temperature showed a warming trend, while the 
diurnal temperature range (DTR) was found to be decreasing for the studied period [16]. Marahatta et al., (2009) [17] also analyzed the temperature trends all over Nepal based on data from 1976 2005 and found that the maximum temperature was found to be increasing at a greater rate $\left(0.05^{\circ} \mathrm{C} /\right.$ year $)$ than the minimum temperature $\left(0.03^{\circ} \mathrm{C} /\right.$ year $)$.

In 2015, DHM of Nepal (www.dhm.gov.np/) [13] conducted a study based on the trend analysis of air temperature and precipitation for the period of 1971-2012 and hence identified an increasing trend on both minimum and maximum temperature in almost all the seasons. The average trend of mean annual minimum and maximum temperature over Nepal was only $0.01^{\circ} \mathrm{C} /$ year and $0.04^{\circ} \mathrm{C} /$ year, respectively. Another noteworthy finding of this report was that the mean annual temperature trend was found lower in the High altitude region while higher in the low altitude Terai and Siwalik range. At the same time, the reverse trend pattern was observed for mean annual maximum temperature with higher in high altitude region and lower in low altitude Terai.

In particular, this study for air temperature trend during seven years period (2011-2017) has benefited from several early research work by DHM (2017) [18], Shrestha et al. (2010, 2016) [19, 20], Hazo et al. (2020) [21]. Such type of research works promotes future researches to be done on climatic variability based on different climatic parameters in account to local communities.

The paper is organized as follows. First, in section II we discuss few related works that are performed on various years regarding air temperature and climate change. In section III, the methodology and device used in this work are best described with the necessary explanation. Based on this methodology, various graphs are produced in section IV along with statistical analysis. These graphs help to get a better understanding of air temperature trends for seven consecutive years. Section V concludes the work and gives a future perspective.

\section{Methodology}

Kathmandu valley is situated in the middle part of Nepal. It lies between the latitude of $27^{\circ} 32^{\prime} 13^{\prime \prime}$ and $27^{\circ} 49^{\prime} 10^{\prime \prime}$ North and longitude of $85^{\circ} 11^{\prime} 31^{\prime \prime}$ and $85^{\circ} 31^{\prime} 38^{\prime \prime}$ East with the mean elevation of about 1300 meters (4265 feet) above sea level [17]. The east-west and north-south axis of this valley are about $30-20 \mathrm{~km}$, respectively [22]. For this study, we have taken the data of the Tribhuvan International Airport (TIA) station located in the Kathmandu valley, where various sensors are attached to detect various climatic parameters. Air temperature and relative humidity sensors are used to determine the temperature and relative humidity. It was a digital sensor in which the temperature ranges from -40 to $124.2^{\circ} \mathrm{C}$ with $\pm 0.1^{\circ} \mathrm{C}$ at 6 to $40^{\circ} \mathrm{C}$ and incorporates a resolution of $0.01^{\circ} \mathrm{C}$ typical [23]. A data logger is connected to the sensor to capture real time automatically. The analog signals from these sensors are converted to a digitally readable format by the microcontroller. [23].

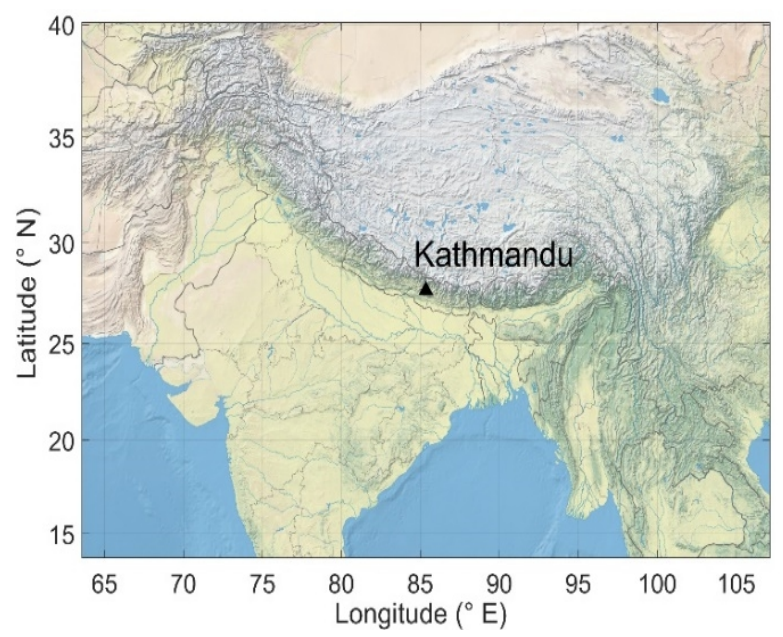

Fig. 1: Location Map of Kathmandu valley. 
Data for the respective stations were collected and published by the DHM of Nepal. The collected data were based on a day-wise maximum and minimum air temperature for each year. The mean monthly maximum and minimum temperature are calculated for 12 months of every year from 2011 to 2017, and the necessary analysis and interpretation of the data for the related study was done by using pandas and matplotlib data visualization of Python.

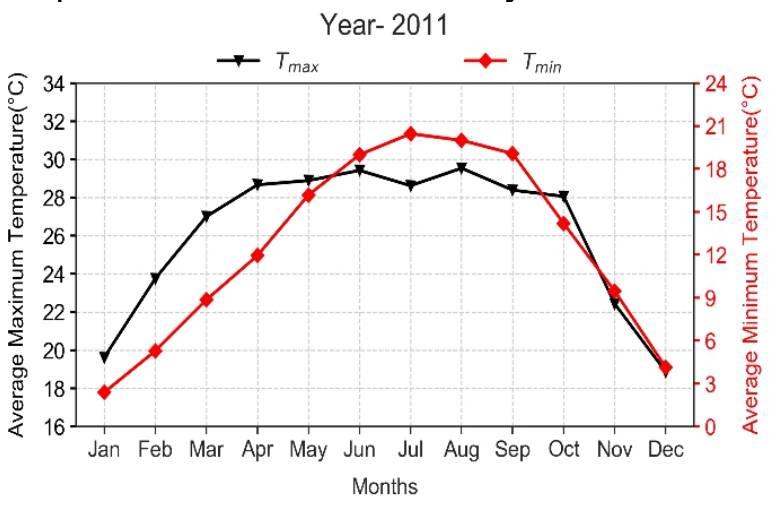

Year- 2012
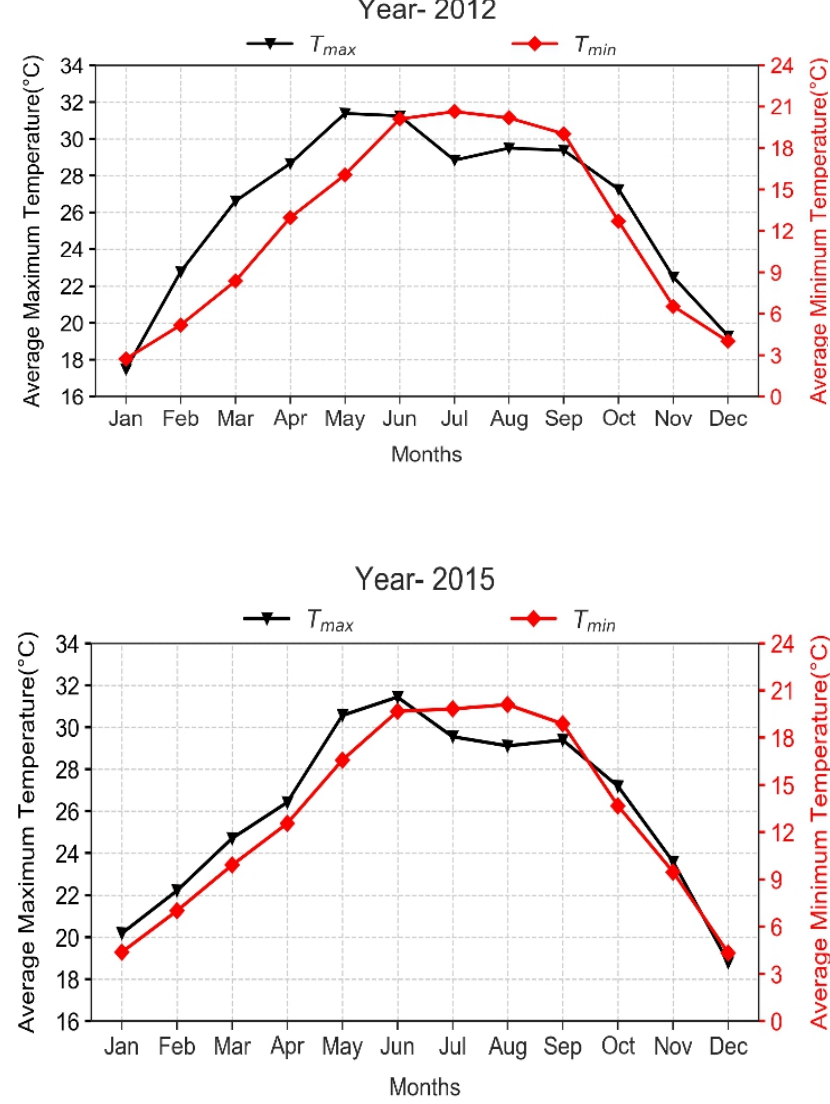

\section{Result and Discussion}

Based on the methodology discussed in the previous section, the monthly variation of an average minimum and maximum air temperature of Kathmandu valley for 7 consecutive years i.e., from 2011 to 2017 is depicted in Fig. 2.
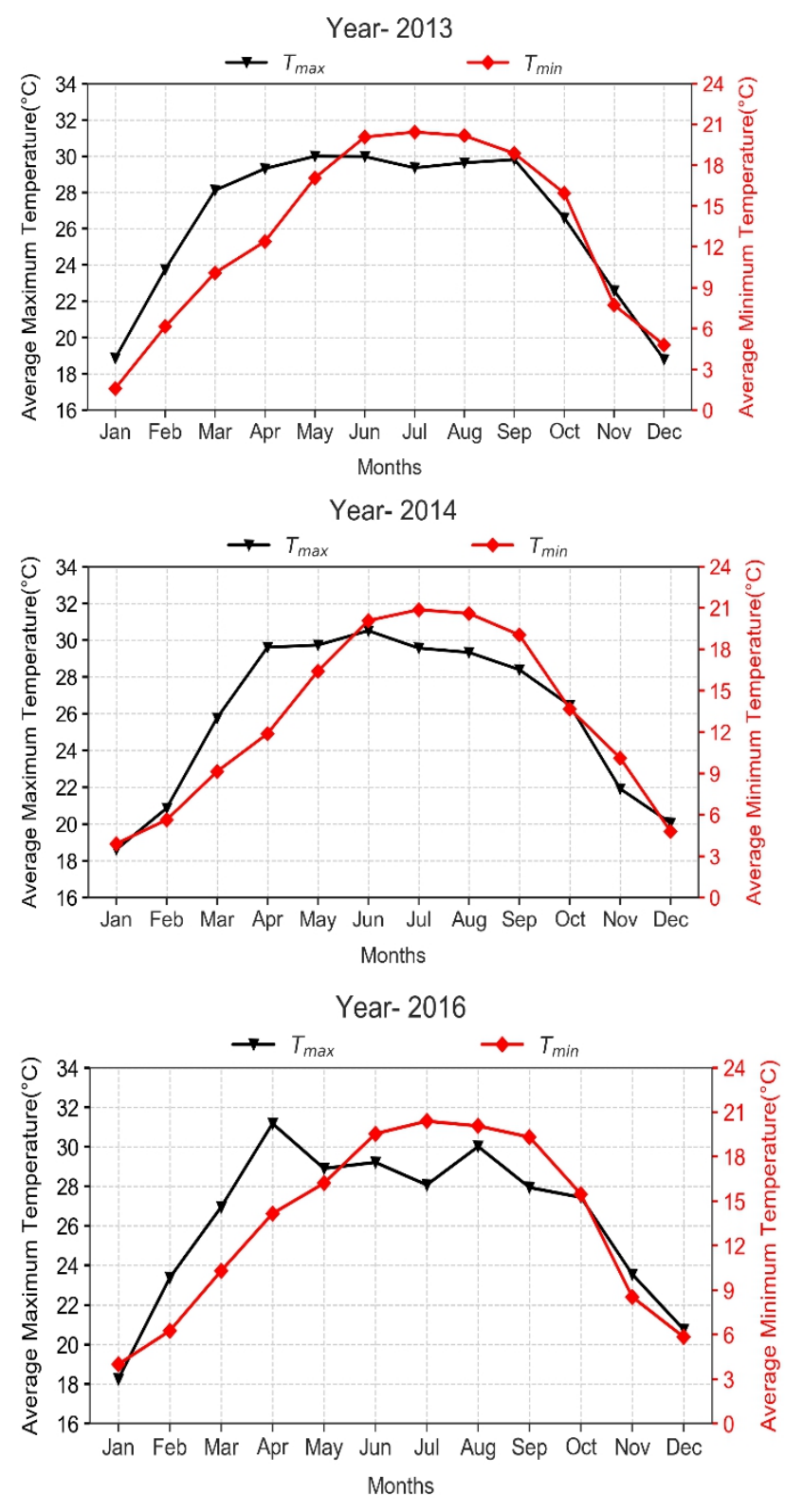


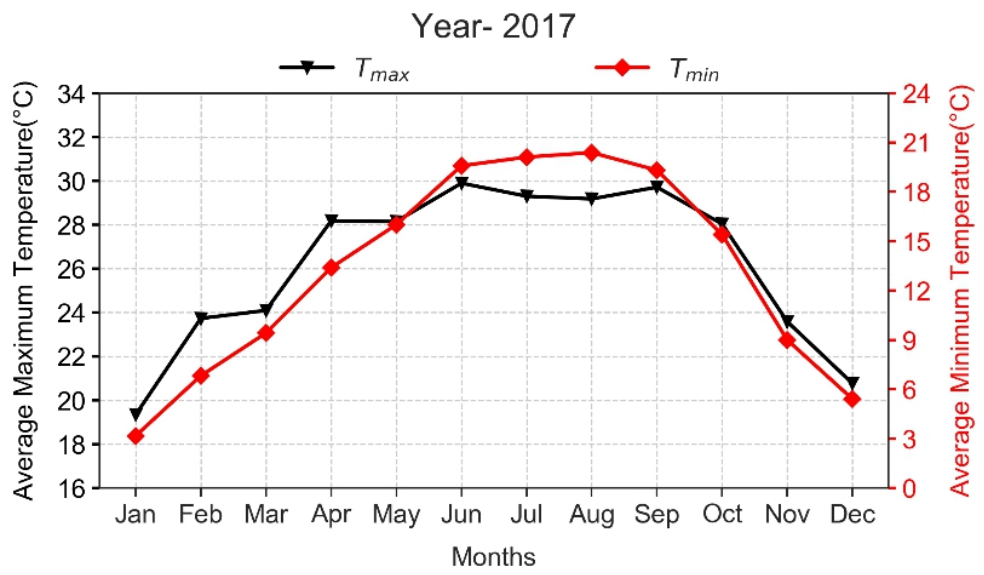

Fig. 2: Monthly Variation of average minimum and maximum temperature during 2011-2017.

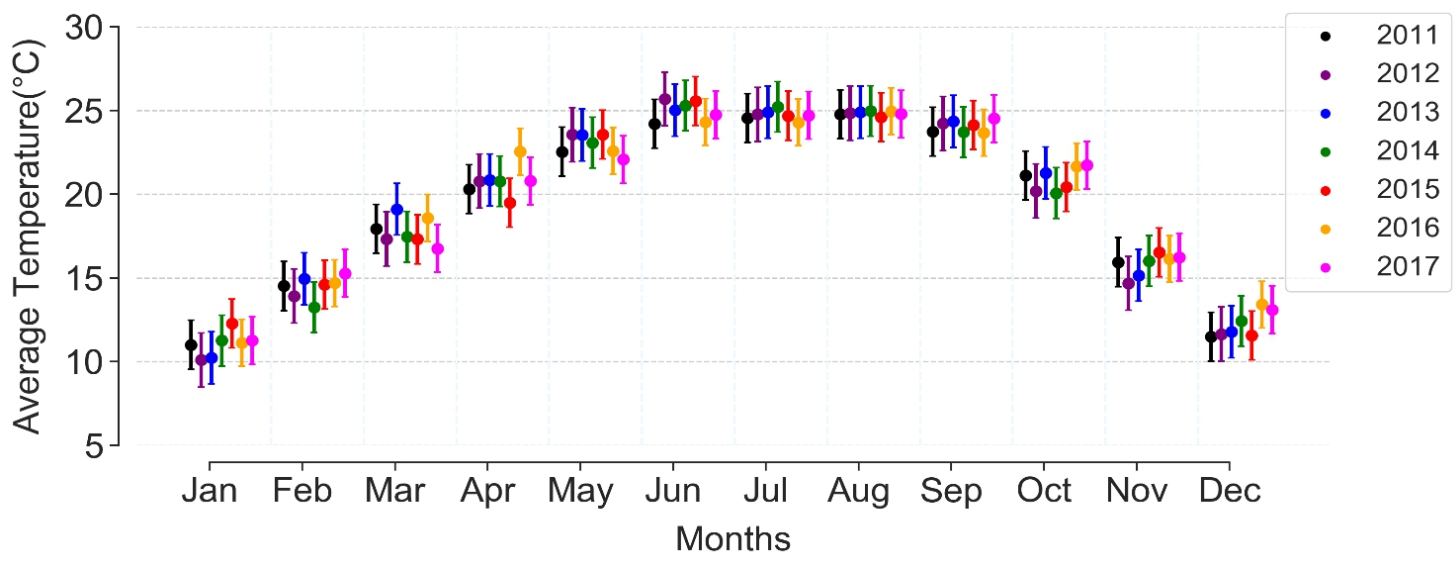

Fig. 3: Monthly Variation of mean air temperature during 2011-2017.

\section{Discussion}

The comparative study shows that January and December, which falls on the winter season, is found to be the coldest month of the year with an average temperature of $\sim 10^{\circ} \mathrm{C}-11^{\circ} \mathrm{C}$ while June, July, and August (summer season) are found to be the warmest month of the year with an average temperature of $\sim 24^{\circ} \mathrm{C}-25^{\circ} \mathrm{C}$. This is due to the fact that the winter season has the shortest day lengths while the summer season has the longest day lengths. The longer that a day lasts, the earth will get more time to absorb energy from the sun. Thus, longer days result in warmer days and shorter days in cooler days. Another noteworthy finding of this study is the average air temperature trend in the coldest and hottest month. The average temperature during the coldest month rises to 2015 and then it falls back again whereas this trend is significantly different in the hottest month. The average temperature during the warmest month for each year is fluctuating as shown in Fig 3.

The reason behind the fluctuation in average air temperature is the gradual increase in minimum temperature $\left(0.097^{\circ} \mathrm{C} /\right.$ year $)$ than the maximum temperature $\left(0.06^{\circ} \mathrm{C} /\right.$ year $)$ as it slowly surpasses the maximum air temperature while taking the average. 
The reason behind the fluctuation in average air temperature is the gradual increase in minimum temperature $\left(0.097^{\circ} \mathrm{C} /\right.$ year $)$ than the maximum temperature $\left(0.06^{\circ} \mathrm{C} /\right.$ year $)$ as it slowly surpasses the maximum air temperature while taking the average.

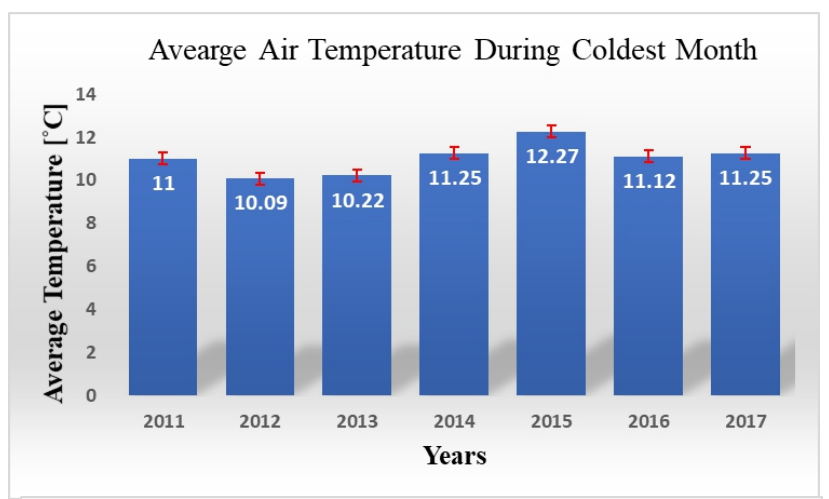

Avearge Air Temperature During Hottest Month

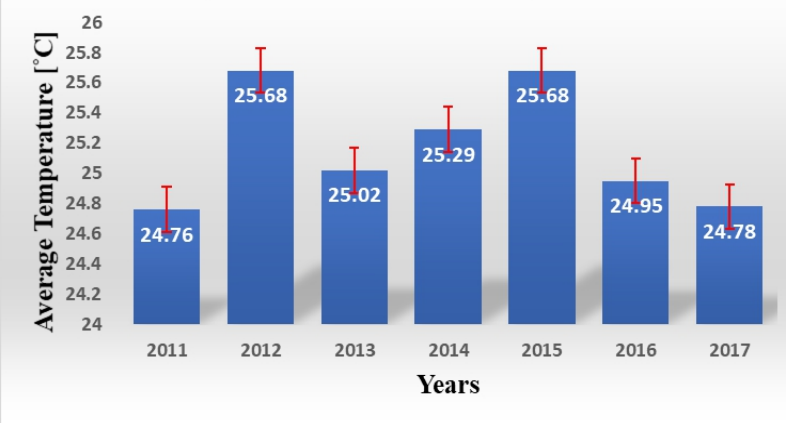

Fig. 4: Average air temperature trend during (a) the coldest month and (b) the hottest month during 2011-2017.

The air temperature usually rises and drops faster just after the sunrise and just before the sunset. But, again, the air temperature takes around 8 hours to rise from the lowest to the highest point, whereas it takes more than $\sim 15$ hours to fall from the highest to the lowest. It relies on the fact that the Earth's surface absorbs the light easily and converts it into heat energy, but the heat, once generated, is not easily escaped from the atmosphere because the atmosphere acts as a blanket and blocks the outgoing radiation [23].

Surface solar radiation is a factor that drives the diurnal cycle of surface air temperatures. This is due to the fact that clouds significantly modulate solar radiation. As a result, clouds have the greatest impact on the maximum temperature $\left(\mathrm{T}_{\max }\right)$ and diurnal temperature range (DTR) [24]. In addition, the atmospheric water vapor has a smaller effect on DTR and it also increases both $\mathrm{T}_{\max }$ and minimum temperature $\left(T_{\min }\right)$ because its greenhouse warming effect has little diurnal variation. Wind speed and the direct evaporative cooling of precipitation seem to have small effects on DTR [24]. Wind speed, relative humidity, rainfall, solar radiation, and other factors can all contribute to temperature fluctuations.

The annual average minimum and maximum temperature, along with the mean annual temperature, are listed in table 1 . The data is then analyzed, and the results are processed to obtain Figures 4, 5, and 6 .

Table 1: Descriptive statistics of the air temperature trends rate for seven years.

\begin{tabular}{|l|l|l|l|}
\hline Year & $\begin{array}{l}\text { Average Min. } \\
\text { Temperature } \\
{\left[{ }^{\circ} \mathrm{C}\right]}\end{array}$ & $\begin{array}{l}\text { Average } \\
\text { Max. } \\
\text { Temperature } \\
{\left[{ }^{\circ} \mathrm{C}\right]}\end{array}$ & $\begin{array}{l}\text { Mean } \\
\text { Temperature } \\
{\left[{ }^{\circ} \mathrm{C}\right]}\end{array}$ \\
\hline 2011 & 12.61 & 26.11 & 19.36 \\
\hline 2012 & 12.40 & 26.25 & 19.32 \\
\hline 2013 & 12.97 & 26.40 & 19.69 \\
\hline 2014 & 13.04 & 25.92 & 19.48 \\
\hline 2015 & 13.05 & 26.10 & 19.58 \\
\hline 2016 & 13.35 & 26.29 & 19.82 \\
\hline 2017 & 13.19 & 26.16 & 19.68 \\
\hline
\end{tabular}

Figs. 4 and 5 show the annual average minimum temperature and annual average maximum temperature with their corresponding linear fit. What we observed is that the dependency of average minimum air temperature on subsequent years was significant (high $\mathrm{R}^{2}$ of 0.756 ). On the other hand, it became insignificant for the case of 
average maximum air temperature (very low $\mathrm{R}^{2}$ of 0.001). Also, Fig. 6 shows the annual mean air temperature with its linear fit. Comprising all the data, i.e., for the entire period of 2011 - 2017, the correlations were higher $\left(\mathrm{R}^{2}\right.$ of 0.601$)$.
The slopes of the trend lines for average minimum air temperature were found to be much higher than those for average maximum air temperature.

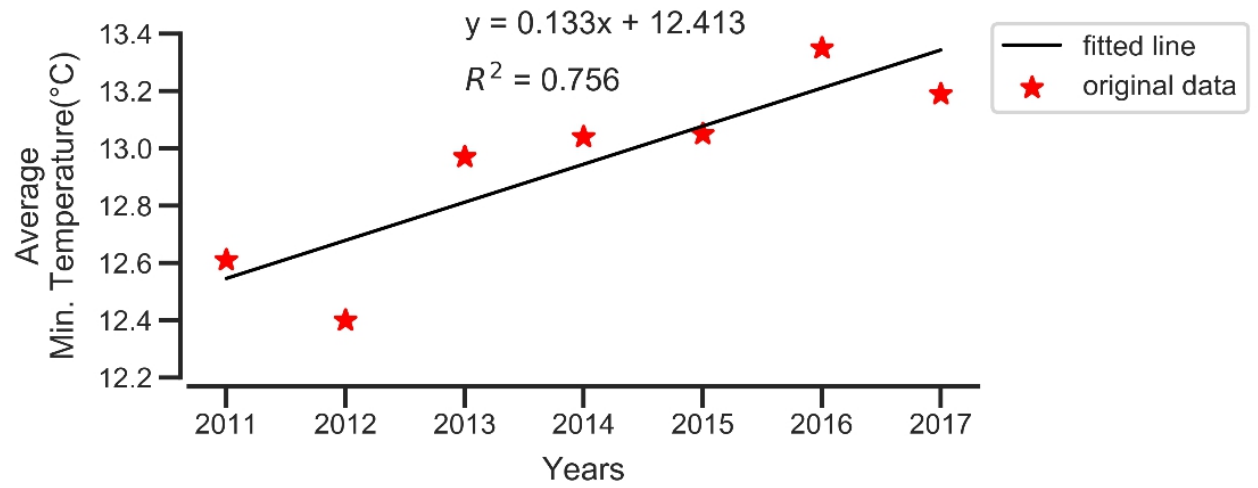

Fig. 4: Best Fit Line for Average Minimum Temperature Trend for the period 2011-2017.

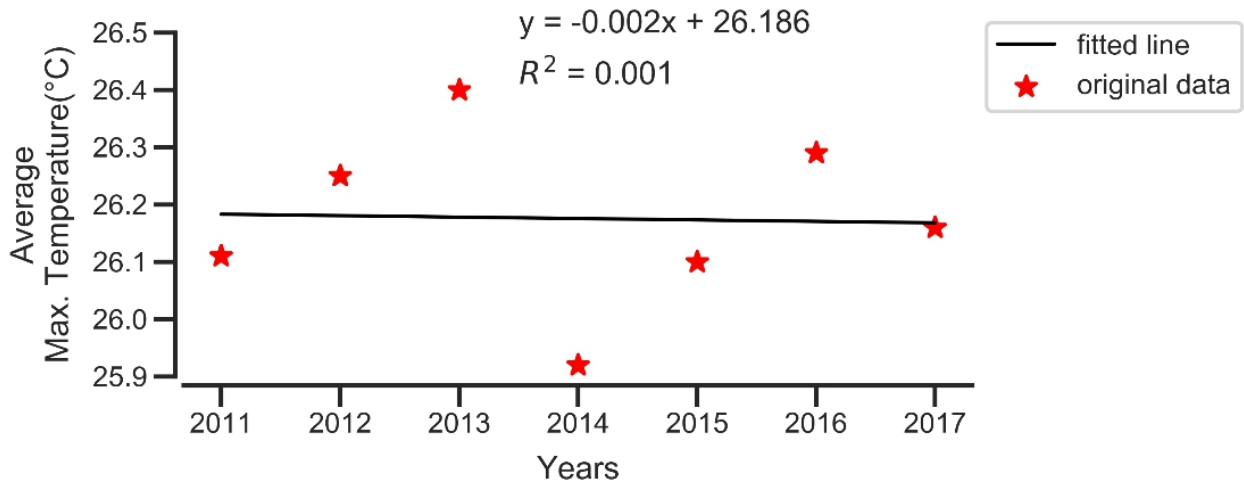

Fig. 5: Best Fit Line for Average Maximum Temperature Trend for the period 2011-2017

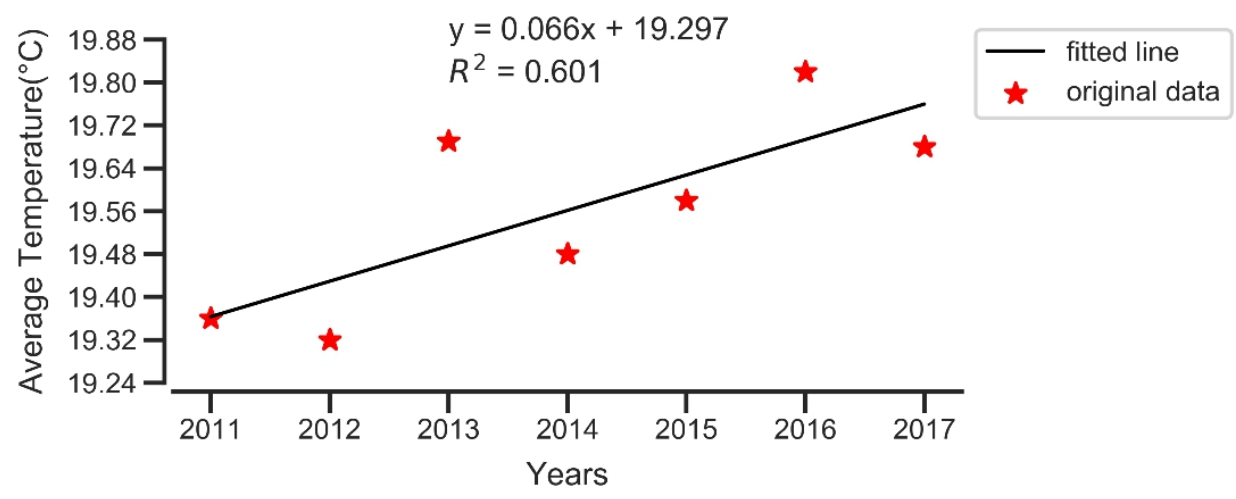

Fig. 6: Annual mean air temperature trends of the Kathmandu valley during 2011-2017. 
Regarding the air temperature, annual average minimum, maximum by mean air temperature shows increasing trends based on the data of the year 2011-2017. The annual average minimum and maximum air temperature trends were found to be increasing significantly at the rate of $0.097^{\circ} \mathrm{C} /$ year and $0.04^{\circ} \mathrm{C} /$ year respectively, while the mean annual maximum temperature was found to be increasing with the rate of $0.06^{\circ} \mathrm{C} /$ year. The anthropogenic activities, local and regional climate have triggered to increase in the air temperature in the Kathmandu valley of Nepal.

The majority of the agricultural land of Kathmandu valley has been turned to an impervious surface layer, drastically altering the valley's landscape [25]. The climatic and weather conditions of the Kathmandu valley have changed dramatically over the last few decades as a result of rapid urbanization [26,27]. Prior to the early detection of the greenhouse effect, comprehensive and timely studies of the effects of urbanization on long-term temperature trends are also needed.

\section{Conclusion}

The present study was keenly focused on analysis of recent air temperature trends in the Kathmandu valley, the capital city of Nepal. Although, the main focus of the study is to estimate the recent temperature trends on the annual minimum and maximum air temperature, the monthly average variation of air temperature for 2011-2017 was also analyzed with the necessary explanation. The monthly variation pattern of air temperature every year demonstrates that they have the highest value in summer while (June, July, and August) and lowest in winter (January and December). The year 2016 was found to be the warmest year among all the other years with an annual mean temperature of $19.82^{\circ} \mathrm{C}$ and 2012 with the least warm with an annual mean temperature of $19.32^{\circ} \mathrm{C}$. Although the average monthly air temperature shows a similar pattern, the average temperature during the coldest and hottest month of every year shows a slightly different pattern. We witnessed a steep increase in the minimum temperature trends $\left(0.097^{\circ} \mathrm{C} /\right.$ year $)$, and a slight increase in maximum temperature trends $\left(0.04^{\circ} \mathrm{C} /\right.$ year $)$, and it affects the average air temperatures of every month and season. The annual mean temperature of Kathmandu valley was found to be increasing at the rate of $0.06^{\circ} \mathrm{C}$ /year.

For the studied period, it has been witnessed that the average temperature during the coldest month varies from $10.09{ }^{\circ} \mathrm{C}-12.27{ }^{\circ} \mathrm{C}$, while $24.76{ }^{\circ} \mathrm{C}$ $25.68{ }^{\circ} \mathrm{C}$ during the hottest months, which suggests a relative change in the frequency of warmer days or cold nights. Without this sort of environmental information coming from research work, plans for dealing with climate change would be scientifically baseless. We believe that the study of such climatic variables helps to understand, analyze and predict the impact of climate change, and contributes to a more precise estimation of global climate change required by policymakers to formulate effective strategies along the lines of mitigation and adaptation of the climate change. To our understanding, the influence of urban warming has only been researched superficially, but we agree that a rigorous investigation of this issue should be prioritized to raise awareness of the negative effects of climate change. Due to rapid urbanization, fluctuations or changes in climatic parameters are a recurring phenomenon in the Kathmandu valley. As a result, the concerned organization should concentrate on developing a climate change adaptation plan to deal with potential climate variability extremes, which could reduce the magnitude of economic, social, and human losses.

\section{Acknowledgment}

The DHM of Nepal is highly acknowledged for providing data of air temperature. We are also thankful to Dr. Indra Bahadur Karki for rendering valuable comments for improving this paper.

\section{Author contributions}

This work is conducted with group efforts of all the authors at all stages. All of the required computational work was carried out by A. Silwal and S.P. Gautam. 


\section{References}

[1] Y. P. Timilsina, Chronological Trend of Climate in the Lumle Village Development Committee from Kaski District, Nepal, International Journal of Interdisciplinary Studies 3 (2015) 53-64. https://doi.org/10.3126/ctbijis.v3i1.14090

[2] Intergovernmental Panel on Climate Change [IPCC], Climate Change: Synthesis Report, Contribution of Working Groups I, II and III to the Fifth Assessment Report of the IPCC (2014).

https://www.ipcc.ch/site/assets/uploads/2018/05/S YR_AR5 FINAL full wcover.pdf

[3] The Royal Society and the US National Academy of Sciences Climate Changes: Evidence and Causes, An overview (2014).

https://royalsociety.org/ /media/royal_society_cont ent/policy/projects/climate-evidencecauses/climate-change-evidence-causes.pdf

[4] Y. Cui et al., Influence of urbanization factors on surface urban heat island intensity: A comparison of countries at different developmental phases, Sustainability 8 (2016) 706. https://doi.org/10.3390/su8080706

[5] M. Jin et al., The footprint of urban areas on global climate as characterized by MODIS, J. Clim. 18 (2005) 1551-1565. https://doi.org/10.1175/jcli3334.1

[6] C. Lavaysse et al., Towards a monitoring system of temperature extremes in Europe. Nat. Hazards Earth Syst. Sci. 18 (2018) 91-104. https://doi.org/10.5194/nhess-18-91-2018

[7] J. J. Li et al., Remote sensing evaluation of urban heat island and its spatial pattern of the Shanghai metropolitan area, China, Ecol. Complex. 6 (2009) 413-420. https://doi.org/10.1016/j.ecocom.2009.02.002

[8] K. E. Ukhurebor et al., The influence of air temperature on the dew point temperature in Benin City, Nigeria, Journal of Applied Sciences and Environmental Management 21 (2017) 657-660. https://doi.org/10.4314/jasem. v21i4.5

[9] P. D. Howe et al., Global perceptions of local temperature change, Nat. Clim. Change, 3 (2012) 352-356.

https://doi.org/10.1038/nclimate 1768

[10] S. Strauss, B. S. Orlove, Weather, climate, culture, $1^{\text {st }}$ Edition, Berg, Oxford (2003).
[11] B. Geerts, Empirical estimation of the monthlymean daily temperature range, Theor. Appl. Climatol 73 (2002) 101-132. https://doi.org/10.1007/s00704-002-0715-3

[12] P. Koirala et al., Estimation of soil erosion in Nepal using a RUSLE Modeling and Geospatial tool, Geosciences 9 (2017) 147. https://doi.org/10.3390/geosciences 9040147

[13] Nepal Hydrological and Meteorological Research Centre and Consultancy Pvt. Ltd., Study of Climate and climatic variation over Nepal (2015) 36. http://www.dhm.gov.np/climate/

[14] K. Frimpong et al., Recent trends in temperature and relative humidity in Bawku East, Northern Ghana, Journal of Geography and Geology 6 (2014) 69-81. https://doi.org/10.5539/jgg.v6n2p69

[15] A. B. Shrestha et al., Maximum Temperature Trends in the Himalaya and Its Vicinity: An Analysis Based on Temperature Records from Nepal for the Period 1971-94, J. Clim. 12 (1999) 2775-2786.

https://doi.org/10.1175/15200442(1999)012<2775:MTTITH $>2.0 . \mathrm{CO} ; 2$

[16] Q. You et al., Changes in daily climate extremes in the eastern and central Tibetan Plateau during 1961 to 2005, J. Geophys. Res. 113 (2008) 1-17. https://doi.org/10.1029/2007JD009389

[17] S. Marahatta et al., Temporal and Spatial Variability of Climate Change over Nepal (19762005), Practical Action, Kathmandu, 2009.

[18] DHM, Observed Climate Trend Analysis in the Districts and Physiographic Regions of Nepal (1971-2014). Department of Hydrology and Meteorology, Kathmandu, (2017).

[19] A. B. Shrestha, L. P. Devkota, Climate Change in the Eastern Himalayas: Observed Trends and Model Projections. Climate Change Impact and Vulnerability in the Eastern Himalayas - Technical Report 1. ICIMOD, Kathmandu (2010).

[20] A. B. Shrestha et al., Observed trends and changes in daily temperature and precipitation extremes over the Koshi river basin 1975-2010. J. Clim. 37 (2016) 1066. https://doi.org/10.1002/joc.4761 
[21] A. IsahHazo et al., Analysis of Trends and Variability in Air Temperature as Evidence of Climate Change in Zaria, Kaduna State, Nigeria, International Journal of Scientific Research in Multidisciplinary Studies 6 (2020) 1-11.

[22] S. Pokhrel, Green space suitability evaluation for urban resilience: an analysis of Kathmandu Metropolitan city, Nepal, Environ. res. commun. 1 (2019) 1-16. https://doi.org/10.1088/2515-7620/ab4565

[23] A. K. Shrestha et al., Solar Radiation, Air Temperature, Relative Humidity, and DewPoint Study: Damak, Jhapa, Nepal, Int. J. Photoenergy. (2019) Article ID 8369231 https://doi.org/10.1155/2019/8369231

[24] A. Dai et al., Effects of Clouds, Soil Moisture, Precipitation, and Water Vapor on Diurnal Temperature Range, J. Clim. 12 (1999) 2451-2473. https://doi.org/10.1175/15200442(1999)012<2451:EOCSMP $>2.0$. CO 2

[25] [A. Ishtiaque et al., Rapid urban growth in the Kathmandu Valley Nepal: Monitoring land use land cover dynamics of a Himalayan City with Landsat Imageries, Environments 4 (2017) 72 .

http://dx.doi.org/10.3390/environments4040072.

[26] S. P. Gautam et al., Comparative Study of Ambient Air Quality Using Air Quality Index in Kathmandu City, Nepal, IOSR-JESTFT 14(5) (2020) 29-35. https//doi.org/10.9790/2402-1405022935

[27] B. Baral \& K. Thapa, Effect of COVID-19 Lockdown on Ambient Air Quality In Major Cities of Nepal, JH\&P 11(29) (2021) 17 .

https://doi.org/10.5696/2156-9614-11.29.210211 